\title{
PENYELIDIKAN MAZMUR AKROSTIK
}

\section{Sia Kok Sin}

\begin{abstract}
Abstrak: Pola akrostik merupakan salah satu pola yang terdapat dalam puisi Ibrani, di antaranya terdapat dalam kitab Mazmur. Mazmur yang mempunyai pola Akrostik ini disebut sebagai mazmur akrostik. Pola ini biasanya diartikan sebagai pola yang menggunakan urutan alfabet Ibrani dari huruf awal kata pertama dari tiap baris disusun. Para ahli mengungkapkan beberapa fungsi pola akrostik dalam mazmur-mazmur akrostik, yaitu untuk menyampaikan sesuatu yang lengkap atau sempurna, alat pendidikan yang memudahkan untuk menghafal dan suatu bentuk artistik yang menunjukkan keahlian penyairnya.
\end{abstract}

Kata Kunci: Mazmur Akrostik, Pengertian Umum, Fungsi

Abstract: Acrostic pattern is one of characteristics in Hebrew poetry. This pattern can be found in several Psalms which are called as Acrostic Psalms. This pattern is regularly marked off by words beginning with Hebrew alphabet sequence. Scholars state some functions of the acrostic pattern, namely a pattern that implies completenesss, a mnemonic tool and an artistic device.

Key Words: Acrostic Psalms, General View, Function

Dalam konteks studi Biblika istilah "akrostik" merupakan suatu istilah yang biasa dikenal ketika seseorang mempelajari bagian-bagian puisi dari Perjanjian Lama. Ada beberapa bagian Perjanjian Lama yang mempunyai pola akrostik, seperti Mazmur 9, 
10, 25, 34, 37, 111, 112, 119 dan 145, Amsal 31:10-31, dan Ratapan 1-4.

Tulisan ini bertujuan untuk memberikan gambaran umum tentang pola akrostik dalam kitab Mazmur dan apa yang dapat dipelajari melalui gambaran umum itu. Dengan harapan agar pembaca dapat menyadari kompleksitas problematika mazmur akrostik, namun tetap memperoleh manfaat dari gambaran umum ini bagi studi penyelidikan kitab Mazmur.

\section{APAKAH POLA AKROSTIK ITU?}

Salah satu gaya puisi Ibrani yang menarik perhatian pembaca kitab Mazmur adalah pola akrostik. M.J. van Eijezeren menyatakan bahwa istilah "akrostik" berasal dari istilah Yunani $\alpha \kappa \rho \circ \sigma \chi 1 \delta \alpha$ yang terdiri dari "across" (bagian terluar) dan "stichos" (sebuah baris dari puisi). ${ }^{1}$

Leslie D. Maloney mengungkapkan pola akrostik (pola yang menggunakan urutan abjad atau huruf) ada 3 jenis yaitu: ${ }^{2}$

1. Huruf awal kata pertama dari tiap baris dapat menjadi suatu nama pribadi jika dibaca secara menurun.

2. Huruf awal kata pertama dari tiap baris dapat menjadi suatu kalimat jika dibaca secara menurun.

3. Huruf awal kata pertama dari tiap baris disusun berdasarkan urutan alfabet.

1 M. J. van Eijezeren, "An Exploration into the Translation of Biblical Acrostics", (M. A. Thesis, Utrecht University, 2012), 4.

${ }^{2}$ Leslie D. Maloney, "A Word Fitly Spoken. Poetic Artistry in the First Four Acrostics of the Hebrew Psalter”, (Dissertation, Baylor University, 2005). 
Selanjutnya Maloney mengungkapkan bahwa jenis 1 dan 2 merupakan pola yang terdapat dalam literatur Babel, sedangkan jenis ketiga merupakan pola akrostik dalam Alkitab Ibrani. Secara umum dalam kaitan dengan mazmur-mazmur akrostik, puisi dengan pola akrostik dipahami sebagai puisi yang huruf pertamanya mempunyai pola tertentu, yaitu berdasarkan urutan alfabet. $^{3}$ Dalam kitab Mazmur terdapat mazmur-mazmur yang mempunyai pola akrostik, yaitu Mazmur 9, 10, 25, 34, 37, 111, 112,119 dan $145 .^{4}$

\section{STUDI PARA AHLI}

Mazmur-mazmur akrostik telah menjadi topik pembahasan pelbagai ahli dengan pelbagai pendekatan dan kedalamannya ("kerumitannya"). Kompleksitas pola akrostik menyebabkan para ahli biasanya hanya membahas suatu aspek dari pola ini dari tulisan-tulisan mereka, sehingga tulisan-tulisan yang ada menunjukkan adanya keragaman dalam pembahasannya.

David Noel Freedman telah melakukan studi pola akrostik yang detail, khususnya dengan dikaitkan dengan meter, penghitungan suku kata dan penghitungan tekanan. ${ }^{5}$ Freedman menyelidiki pola akrostik yang terdapat pada kitab Ratapan, Mazmur dan Amsal. Dalam kaitan dengan pola akrostik dalam kitab Mazmur Freedman mengungkapkan adanya pola umum, yaitu pola tekanan 3:3 dalam bicola dan 16 suku kata dalam tiap baris

\footnotetext{
${ }^{3}$ Wilfred G. E. Watson, "Classical Hebrew Poetry. A Guide to its Techniques" in JSOT Supp. Series 26, (Sheffield: JSOT Press, 1984), 190.

${ }^{4}$ Tremper Longman III, Bagaimana Menganalisa Kitab Mazmur? (Malang: SAAT, 1994), 122.

${ }^{5}$ David Noel Freedman, "Acrostics and Metrics in Hebrew Poetry", in Harvard Theological Review 65, (1972), 367-92; David Noel Freedman, "Acrostic Poems in the Hebrew Bible: Alphabetic and Otherwise", in The Catholic Biblical Quaterly, 48, (1986), 408-31.
} 
(8:8) dalam bicola. Ia juga mengakui adanya variasi, seperti pola tekanan 4:2 dalam bicola, pola 15 atau 17 suku kata dalam tiap baris, pola 7 dan 9 suku kata dalam bicola ataupun variasi lainnya. Pola standar akrostik terdiri dari 22 baris, walau ada yang 23 baris atau variasi lainnya. Penyelidikan Freedman lebih berkaitan dengan kekhasan meter, jumlah suku kata dan tekanan dalam pola akrostik, sehingga ia tidak membahas problematika pola akrostik yang tidak "sempurna" atau "lengkap" dan bagaimana harus menyingkapinya.

Leslie D. Maloney menulis disertasi yang menyelidiki keempat mazmur akrostik dari Mazmur Jilid I (Mazmur 9-10, 25, 34, 37) dalam kaitannya dengan keempat mazmur akrostik dari Mazmur Jilid V (Mazmur 111, 112, 118, 145). ${ }^{6}$ Maloney tidak berfokus pada penyelidikan teknik akrostik pada mazmur-mazmur akrostik ini, tetapi lebih berfokus pada penyelidikan gramatikal, stylistik dan semantik dari keempat mazmur akrostik pada Jilid I serta hubungan intertekstualitas antara mazmur-mazmur akrostik dari Jilid I ini juga dengan mazmur-mazmur akrostik dari Mazmur Jilid V. Penyelidikan Maloney bertujuan untuk membantah anggapan bahwa gaya akrostik pada mazmur-mazmur akrostik ini menyebabkan mazmur-mazmur ini kaku dan tidak imaginatif. Melalui penyelidikannya Maloney justru menunjukkan keindahan mazmur-mazmur akrostik ini dan juga adanya keterkaitan secara gramatikal, stylistik dan semantik di antara mazmur-mazmur akrostik dari Mazmur Jilid I ini atau bahkan dengan mazmurmazmur akrostik dari Mazmur Jilid V.

Ronald Benun berpendapat bahwa pola akrostik merupakan sistem sastra yang rumit (sophisticated literary system) yang menghadirkan petunjuk-petunjuk yang memimpin pembaca untuk

${ }^{6}$ Maloney, “A Word Fitly”. Dissertation. 
menemukan berita yang terkandung dalam suatu mazmur. ${ }^{7}$ Kalau ada suatu gangguan dan ketidaksempurnaan dalam pola akrostik ini justru memberikan petunjuk-petunjuk bagi pembaca. ${ }^{8}$ Benun menyatakan hanya 3 mazmur yang mempunyai pola akrostik yang lengkap (Mazmur 111, 112, 119). Pembaca akan menemukan ketidaklengkapan dan ketidaksempurnaan pola dari suatu mazmur akrostik dan hal ini akan mendorong untuk mencari penjelasannya. Hal ini menurut Benun justru akan menyingkapkan berita yang terkandung dari suatu mazmur. Melalui penyelidikan yang detail dan rumit dari Mazmur 9-10, 25, 34 dan 37 (mazmur-mazmur akrostik dalam kitab Mazmur jilid I) Benun berupaya keras untuk menunjukkan kesengajaan dan kecanggihan pemazmur dalam menghadirkan berita yang terkandung dari suatu mazmur melalui "ketidaksempurnaan" pola akrostik yang umumnya dianggap oleh para ahli sebagai suatu kerusakan teks. Ia juga memaparkan bagaimana terkaitkan berita dari keempat mazmur akrostik ini. Selanjutnya ia menyatakan bahwa keempat mazmur ini merupakan sebuah set yang bergerak dari suatu pengalaman pelbagai kejahatan (Mazmur 9-10) melalui proses pertobatan, belajar dan doa (Mazmur 25) kepada suatu keadaan percaya dan taat kepada Allah (Mazmur 34) dan pada akhirnya pengakuan bahwa Allah itu benar kepada perjanjian-Nya (Mazmur 37). ${ }^{9}$ Penggunaan pola akrostik pada beberapa mazmur bukanlah semata untuk alat bantu mengingat atau keindahan puitis atau bahkan menjadi perusak struktur suatu mazmur, tetapi memang mempunyai tujuan penting untuk pembaca menemukan makna teks-teks itu. ${ }^{10}$

\footnotetext{
${ }^{7}$ Ronald Benun, "Evil and The Disruption of Order: A Structural Analysis of the Acrostics in the First Book of Psalms", in Journal of Hebrew Scriputres vol 6, (2006): 2 .

${ }^{8}$ Benun, "Evil and The Disruption", 2.

${ }^{9}$ Benun, "Evil and The Disruption", 22.

${ }^{10}$ Benun, "Evil and The Disruption", 23.
} 
Sedangkan M. J. van Eijezeren menulis tesis tentang pelbagai kesulitan dalam upaya menerjemahkan teks-teks akrostik dalam Perjanjian Lama dalam bentuk terjemahan yang akrostik juga. ${ }^{11}$ Van Eijezeren membagi pola akrostik menjadi 2 pola, yaitu pola "abecedaria" (pola yang didasarkan pada urutan alfabet) dan pola "non-abecedaria" (pola yang didasarkan pada suatu berita atau "message"). ${ }^{12}$ Pola "abecedaria" dapat ditemukan Mazmur 9, 10, 25, 34, 37, 111, 112, 119 dan 145, Amsal 31:10-31, Ratapan 1-4 dan Nahum 1. ${ }^{13}$ Sedangkan pola "non-abecedaria" terdapat pada Mazmur 96:11 dan kitab Ester, yaitu adanya kata JHWH. ${ }^{14}$ Dalam bagian awal van Eijezeren membahas sekilas tentang pola akrostik yang sempurna dan juga yang "tidak sempurna". Ia berpendapat searah dengan Ronald Benun yang mengungkapkan bahwa "ketidaksempurnaan" dalam pola akrostik merupakan sesuatu yang disengaja oleh pengubahnya dan bukan oleh karena adanya kerusakan teks dalam proses transmisinya. ${ }^{15}$ Van Eijezeren juga menyatakan pelbagai fungsi pola akrostik, di antaranya, menyatakan kelengkapan, mnemonic (untuk memudahkan mengingat), stylistik, kemahiran pengubahnya, keteraturan dan pengaturan, memperkuat beritanya, magis, alat pengajaran, tanda penting bagi berita yang tersembunyi, tanda penolong untuk membaca dan memahaminya, dan lain-lain. ${ }^{16}$ Bagi van Eijezeren sendiri fungsi utama pola akrostik adalah untuk menyatakan kelengkapan. ${ }^{17}$ Walaupun ia menyadari pentingnya antara means dan meaning, pada akhirnya ia harus mengakui bahwa tidaklah

${ }^{11}$ Eijezeren, "An Exploration”, M.A. Thesis.

12 Eijezeren, “An Exploration”, M.A. Thesis., 4.

13 Eijezeren, "An Exploration", M.A. Thesis, 5. Ia juga menyadari bahwa pola akrostik pada Nahum 1 menjadi bahan perdebatan di antara para ahli.

${ }^{14}$ Eijezeren, "An Exploration”, M.A. Thesis, 5.

15 Eijezeren, "An Exploration”, M.A. Thesis, 7.

${ }^{16}$ Eijezeren, “An Exploration”, M.A. Thesis, 37.

${ }^{17}$ Eijezeren, “An Exploration", M.A. Thesis, 37. 
mungkin untuk menerjemahkan teks pola akrostik ke dalam terjemahan dengan pola akrostik pula. ${ }^{18}$

O. Palmer Robertson menyelidiki kaitan antara mazmurmazmur akrostik dengan struktur kitab Mazmur untuk menemukan kontribusi struktural dari mazmur-mazmur akrostik bagi pemahaman kitab Mazmur secara menyeluruh. ${ }^{19}$ Robertson mengungkapkan bahwa 4 mazmur akrostik ini ditempatkan pada kitab Mazmur jilid I (Mazmur 9-10, 25, 34, 37) dan 4 pada jilid V (Mazmur 11, 112, 119, 145) pasti mempunyai makna struktural bagi keseluruhan kitab Mazmur. ${ }^{20}$ Bahkan ia berpendapat bahwa penempatan sebuah mazmur akrostik pada suatu kelompok mazmur juga mempunyai makna penting. Mazmur 9-10 yang menekankan status Yahweh sebagai Raja atas bangsa-bangsa diletakkan sebelum Mazmur 3-8 yang kurang mengungkapkan status Yahweh sebagai Raja atas bangsa-bangsa. ${ }^{21}$ Ada makna penting juga berkaitan dengan penempatan Mazmur 25 sesudah 4 Mazmur raja (Mazmur 20-24) yang mana sebelumnya terdapat Mazmur Mesianis (Mazmur 18) dan Mazmur 19 yang menekankan tentang Taurat, karena Mazmur 25 itu menggemakan fungsi Taurat, sehingga Mazmur 25 merupakan respons terhadap Mazmur $19 .{ }^{22}$ Mazmur akrostik 34 dan 37 memberikan pembatas bagi 4 mazmur yang mengungkapkan ungkapan penderitaan dari orang yang tak bersalah, yang selanjutnya diteruskan oleh satu kelompok yang terdiri 4 mazmur yang mengungkapkan kesulitan-kesulitan yang disebabkan oleh penderitaan dari orang yang bersalah (Mazmur 38-

\footnotetext{
${ }^{18}$ Eijezeren, “An Exploration”, M.A. Thesis, 86.

${ }^{19}$ O. Palmer Robertson, "The Alphabetic Acrostic in Book I of the Psalms: An Overlooked Element of Psalter Structure", in Journal for the Study of the Old Testament vol. 40. 2, (2015): 225-38.

${ }^{20}$ Robertson, "The Alphabetic Acrostic": 225-6.

${ }^{21}$ Eijezeren, “An Exploration”, M.A. Thesis, 226-7.

${ }^{22}$ Robertson, "The Alphabetic Acrostic", 227-8.
} 
41). ${ }^{23}$ Hal menarik lainnya adalah penempatan 3 Mazmur tentang Penciptaan (Mazmur 8, 24, 33) sebelum Mazmur-mazmur akrostik (Mazmur 9-10, 25, 34). ${ }^{24}$ Robertson juga menyatakan salah satu fungsi pola akrostik adalah untuk memudahkan mengingat (mnemonic), bahkan ia menyatakan bahwa penempatan Mazmurmazmur akrostik juga mempunyai fungsi ini, khususnya dalam upaya mengingat suatu kelompok mazmur (seperti Jilid I) atau pun seluruh kitab Mazmur. ${ }^{25}$ Selanjutnya Robertson menekan pentingnya peran Mazmur 9-10 sebagai Mazmur akrostik yang pertama. Penting tidak hanya bagi keseluruhan kitab Mazmur, tetapi juga keseluruhan Kitab Suci. ${ }^{26}$ Memang pola akrostik dalam Mazmur 9-10 sangatlah tidak sempurna, karena banyak huruf yang hilang, tetapi justru Mazmur 9-10 menjadi contoh adanya pelbagai pola akrostik dalam kitab Mazmur. ${ }^{27}$

\section{FUNGSI POLA AKROSTIK}

Para ahli juga memperdebatkan makna dan fungsi dari pola akrostik. Peter C. Craigie mengungkapkan 3 fungsi bentuk akrostik:

1. Suatu bentuk artistik yang mana penyair dapat mengekspresikan pemikirannya dalam bentuk tertentu.

2. Suatu cara pendidikan yang memudahkan untuk menghafal bagi para pelajar.

3. Bentuk ini ingin menyampaikan sesuatu yang lengkap atau sempurna. $^{28}$

\footnotetext{
${ }^{23}$ Robertson, "The Alphabetic Acrostic", 227-8.

${ }^{24}$ Robertson, "The Alphabetic Acrostic", 229-30.

${ }^{25}$ Robertson, "The Alphabetic Acrostic", 230-2.

${ }^{26}$ Robertson, "The Alphabetic Acrostic", 232.

${ }^{27}$ Robertson, "The Alphabetic Acrostic", 236.

28 Peter C. Craigie, Psalms 1-50. WBC 19, (Waco: Word Books, Publishers, 1983), 129.
} 
Selanjutnya Craigie mengungkapkan fungsi pertama merupakan fungsi yang utama, yaitu suatu upaya artistik dari sang penyair.

Wilfred G.E. Watson menyatakan bahwa pola akrostik ini menunjukkan 2 aspek yang jelas, yaitu: "the highly artificial nature of such a scheme and its non-oral character, these poems being intended to appeal to the eye rather than the ear." (suatu pola yang sangat tidak alamiah atau buatan dan mempunyai karakter untuk menarik dalam membaca dan bukan untuk pendengaran). ${ }^{29}$

William Michael Soll mengungkapkan bahwa pola akrostik bukanlah untuk pola pembelajaran dan pengingat, karena pola ini justru lebih tepat untuk mereka yang telah mengenal alfabet dan kemampuan menulis dan membaca. ${ }^{30}$

Longman III menyatakan bahwa tidak ada seorang pun yang tahu fungsi pola akrostik. ${ }^{31}$ Dapat saja merupakan suatu cara untuk menyatakan bahwa Tuhan memberikan susunan yang teratur kepada ciptaan-Nya, walau kemungkinan besar adalah untuk membantu dalam mengingat atau hanya sekedar untuk seni estetika yang menyenangkan para penyair. ${ }^{32}$

O. Palmer Robertson masih mempertahankan fungsi untuk memudahkan menghafal suatu mazmur sebagai salah satu maksud utama pola akrostik dalam suatu mazmur. ${ }^{33}$ Bahkan ia berpendapat bahwa menghafalkan mazmur-mazmur akrostik akan menolong

\footnotetext{
${ }^{29}$ Watson, "Classical Hebrew”, 191.

30 William Michael Soll, "Babylonian and Biblical Acrostics", in Biblica 69, (1988): 321

${ }^{31}$ Longman III, Bagaimana Menganalisa, 122.

${ }^{32}$ Longman III, Bagaimana Menganalisa, 122.

${ }^{33}$ Robertson, "The Alphabetic Acrostic", 230.
} 
seseorang untuk mengetahui daftar isi (table of contents) dan memahami makna kitab Mazmur secara kesuluruhan. ${ }^{34}$

Jadi pelbagai pendapat para ahli tentang fungsi pola akrostik dapat disimpulkan yaitu untuk memudahkan menghafal, menyatakan kelengkapan suatu berita ataupun menyatakan keunggulan artistik sang penyair.

\section{PENYELUSURAN SINGKAT MAZMUR-MAZMUR AKROSTIK}

\section{Mazmur 9 dan 10}

Mazmur 9 dan 10 dalam versi LXX, Vulgata dan beberapa versi Ibrani merupakan satu Mazmur. ${ }^{35}$ Watson menyebut Mazmur 9 dan 10 sebagai 2 mazmur semi-akrostik. ${ }^{36}$ Hans-Joachim Kraus berpendapat bahwa sulit untuk merekonstruksi pola akrostik dari Mazmur 9 dan 10. ${ }^{37}$ Terdapat pola akrostik dalam kedua mazmur ini, karena dalam Mazmur 9 terdapat baris yang dimulai dengan huruf $x$ sampai $\supset$ dan Mazmur 10 terdapat baris yang dimulai dengan huruf $ל$ sampai $ת .^{38}$

Berdasarkan penyelusuran Teks Masoret (MT) dapat ditemukan pola "akrostik" dalam pola huruf $\mathrm{J}$ - Mazmur 9, yaitu א (v.2), ב (v.4), ג (v. 6), > (v. 10), ז (v. 12), ก (v.14), ט (v. 16), ' (v.

\footnotetext{
${ }^{34}$ Robertson, "The Alphabetic Acrostic", 230-1.

${ }^{35}$ Craigie, Psalms 1-50, 116.

${ }^{36}$ Watson, "Classical Hebrew”, 192.

37 Hans-Joachim Kraus, Psalms 1-59, (Minneapolis: Augsburg Publishing House, 1988), 192.

${ }^{38}$ Watson salah dalam menyebut huruf $\supset$ dengan huruf $า$. Bandingkan Watson, “Classical Hebrew”, 192.
} 
18), dan כ (v. 19), serta pola huruf $ל-\Omega$ dalam Mazmur 10, yaitu $ל$ (v. 1), מ (v. 5b), ${ }^{39}$ ק (v. 12), ר (v. 14), ש (v. 15), dan ת (v. 17).

Watson mengungkapkan bahwa pola akrostik dalam Mazmur 10 tidak terlalu jelas. ${ }^{40}$ Sedangkan Craigie dan Kraus berpendapat bahwa kondisi pola akrostik dalam Mazmur 9 dan 10 ini mungkin disebabkan oleh perubahan atau modifikasi editor atau dapat juga merupakan kerusakan teks. ${ }^{41}$ Pendapat ini ditolak oleh Ronald Benun yang berpendapat bahwa "ketidaksempurnaan" pola akrostik Mazmur 9-10 merupakan sesuatu yang disengaja. Melalui penghitungan jumlah kata yang rumit dari Mazmur 9-10 Benun ingin menunjukkan bahwa pola akrostik yang tidak biasa ini sengaja untuk mengungkapkan berita tertentu oleh penyairnya. ${ }^{42} \mathrm{O}$. Palmer Robertson juga yang berpendapat bahwa pola akrostik dalam Mazmur 9 dan 10 ini memang sengaja dibuat sepertinya tidak "regular" oleh penyairnya untuk menjadi contoh atau "sampler" bagi pola akrostik lainnya, yang dapat saja diketemukan "ketidaksempurnaannya". ${ }^{43}$

Jadi ada beberapa pendapat para ahli tentang "ketikasempurnaan" pola akrostik dalam Mazmur 9-10, yaitu kerusakan teks, modifikasi editornya dan pola yang memang disengaja dengan tujuan tertentu.

\section{Mazmur 25}

39 Huruf is sebagai bagian pola akrostik ini merupakan pendapat dari Craigie.

Craigie, Psalms 1-50, 121.

${ }^{40}$ Watson, "Classical Hebrew”, 192.

${ }^{41}$ Craigie, Psalms 1-50, 129; Kraus, Psalms 1-59, 192.

42 Benun, "Evil and The Disruption", 3-11.

${ }^{43}$ Robertson, "The Alphabetic Acrostic", 232-7. 
Penyelusuran teks Masoret Mazmur 25 menunjukkan adanya pola akrostik, walaupun tidak sempurna. Tidak ada huruf $\beth, ~ ı$, dan $P$, sedangkan huruf $ר$ diulang (vv. 18-19). Juga ada penambahan pada ayat terakhir dengan pola huruf פ (v. 22) yang sesudah pola akrostik huruf ת (v. 21).

Kraus mengusulkan beberapa perubahan dalam teks Masoret, sehingga didapatkan pola akrostik yang lengkap (sempurna) dari Mazmur ini. ${ }^{44}$

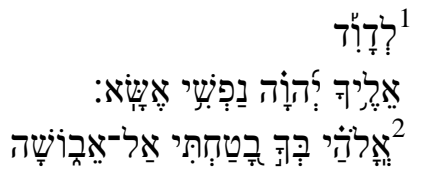

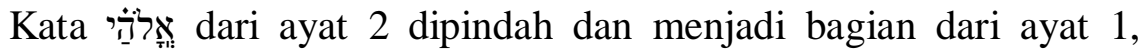
sehingga ayat 2 dimulai dengan kata ㄲำ akrostik yang baik dari ayat 1 dan 2 .

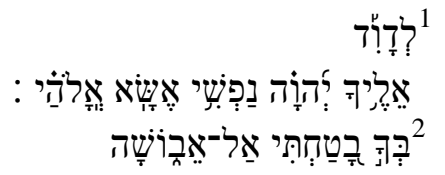

Kraus mengusulkan penambahan huruf ו pada kata pada ayat $5 \mathrm{~b}$, sehingga adanya pola akrostik pada ayat $5 \mathrm{a}$ dan $\mathrm{b}$.

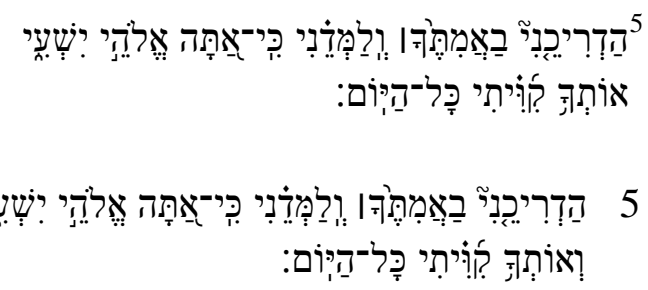

${ }^{44}$ Kraus, Psalms 1-59, 319. 


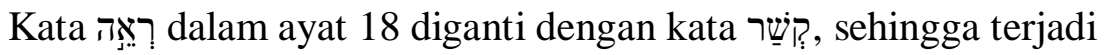
pola akrostik dalam ayat 17-19.

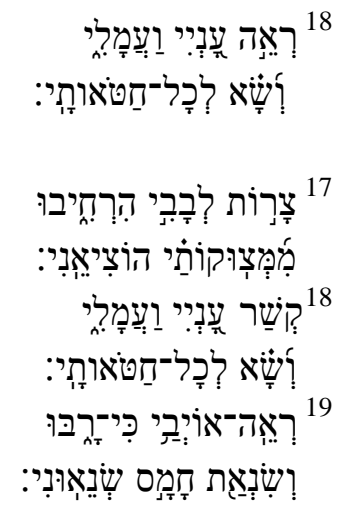

Kraus berpendapat bahwa ayat 22 (pola huruf פ) dianggap sebagai tambahan kemudian, walau ia tidak menjelaskan alasan adanya tambahan ini. Selanjutnya Kraus berpendapat bahwa penggunaan pola akrostik menyebabkan pola yang mengikat dan dapat menyebabkan pengulangan yang tidak perlu ataupun ketidakjelasan alur pemikiran dalam mazmur ini. ${ }^{45}$ Craigie juga berpendapat oleh karena mengikuti pola akrostik ini, penyair mazmur ini tidak dapat mengembangkan alur pemikirannya dengan jelas dalam mazmur ini. ${ }^{46}$

Sedangkan Benun berpendapat bahwa "anomali" pola akrostik ini juga disengaja oleh penyair. Melalui pendekatan intertekstualitas Mazmur 25 dengan Keluaran 33 dan Yeremia 14 justru "anomali" ini menekankan berita yang ingin disampaikan oleh penyair. $^{47}$

\section{Mazmur 34}

\footnotetext{
${ }^{45}$ Kraus, Psalms 1-59, 319.

${ }^{46}$ Craigie, Psalms 1-50, 217.

${ }^{47}$ Benun, "Evil and The Disruption", 11-13.
} 
Mazmur 34 juga menampakkan pola akrostik, walaupun ada beberapa hal yang menyimpang. Tidak ada pola huruf $\mathrm{,} \mathrm{dan} \mathrm{juga}$ ada penambahan pada ayat terakhir dengan pola huruf פ (v. 23) sesudah huruf $\Omega\left(\right.$ v. 22). ${ }^{48}$

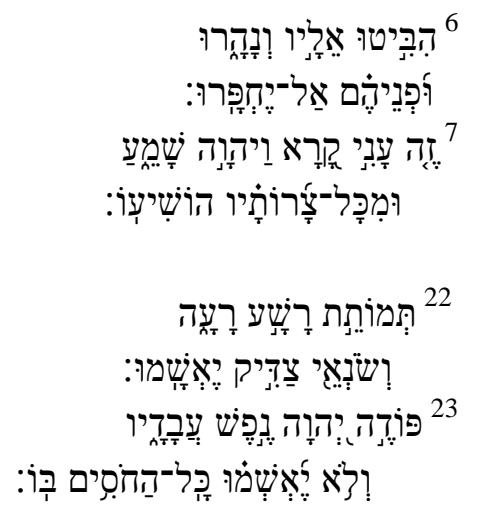

Ada ahli yang mencoba menafsirkan kehadiran tambahan pola huruf $פ$ (v. 23) sesudah huruf $\Omega$ (v. 22) dengan berpendapat bahwa penambahan huruf פ adalah untuk mendapatkan pola huruf (v. 12) sebagai huruf tengah dari seri alfabet yang menjadi 23 huruf (22 huruf alfabet ditambah dengan huruf פ ). Penafsiran ini akan menghadirkan huruf xsebagai huruf pertama, huruf $ל$ sebagai huruf tengah dan huruf $פ$ sebagai huruf terakhir yang mana ketiga huruf ini akan membentuk huruf pertama dari alfabet, yaitu aleph. ${ }^{49}$ Pendapat ini sangat menarik, tetapi yang menjadi persoalan adalah hilangnya pola huruf $\mathrm{q}$ dalam Mazmur 34 ini, sehingga pola huruf $ל$ (v. 12) tidak dapat menjadi huruf tengah dari seri alfabet. Terhadap kondisi ini ada ahli yang mencoba melakukan penghitungan jumlah suku kata yang terdapat dalam Mazmur 34 dan berpendapat bahwa pola huruf $ל$ hampir dalam posisi tengah dari mazmur ini, sehingga terdapat pola huruf ssebagai huruf pertama, huruf $ל$ sebagai huruf

\footnotetext{
${ }^{48}$ Band. Kraus, Psalms 1-59, 382.

${ }^{49}$ Anthony R. Ceresko, "THE ABCS OF WISDOM IN PSALM XXXIV," Vetus Testamentum XXXV, 1 (1985), 100.
} 
tengah dan huruf 9 sebagai huruf terakhir yang mana ketiga huruf ini akan membentuk huruf pertama dari alfabet, yaitu aleph. ${ }^{50}$

\section{Mazmur 37}

Pola akrostik dalam Mazmur 37 adalah pola yang cukup baik, walau tidak sempurna. Craigie menyebutkan bahwa Mazmur 37 ini dapat dijadikan contoh penting dalam pembahasan mazmur akrostik. $^{51}$

Penyelidikan terhadap teks Masoret (MT) Mazmur 37 menunjukkan adanya pola akrostik dari huruf $\mathrm{x}$ sampai $\Omega$, dengan beberapa varisi, seperti penambahan ?ִ pada kata לִ (v. 28b), dan penambahan s pada kata (v. 39)

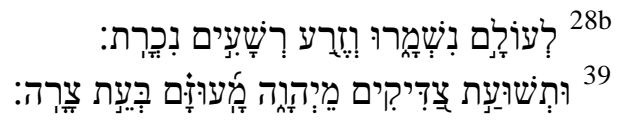

Penggunaan pola akrostik dalam Mazmur 37 ini bagi Craigie juga menyebabkan adanya pembatasan perkembangan pemikiran dalam mazmur ini oleh karena terikat dengan pola akrostik ini. ${ }^{52}$

\section{Mazmur 111}

Mazmur 111 merupakan contoh pola akrostik yang sempurna, karena pola ini rapi berurutan mulai huruf $x$ sampai huruf $\Omega$.

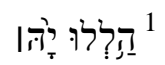

${ }^{50}$ Ini pendapat dari Fitzgerald yang dikutip oleh Ceresko, "THE ABCS OF WISDOM", 100.

${ }^{51}$ Craigie, Psalms 1-50, 296.

${ }^{52}$ Craigie, Psalms 1-50, 296. 


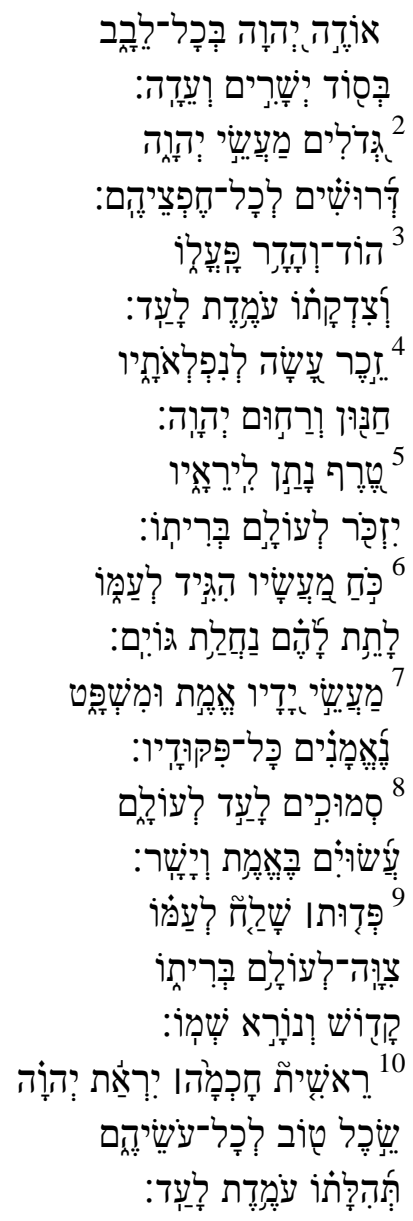

Mazmur 111

1 Haleluya!

Aku mau bersyukur kepada TUHAN dengan segenap hati, dalam lingkungan orang-orang benar dan dalam jemaah.

2 Besar perbuatan-perbuatan TUHAN, layak diselidiki oleh semua orang yang menyukainya.

3 Agung dan bersemarak pekerjaan-Nya, dan keadilan-Nya tetap untuk selamanya. 
4 Perbuatan-perbuatan-Nya yang ajaib dijadikan-Nya peringatan;

TUHAN itu pengasih dan penyayang.

5 Diberikan-Nya rezeki kepada orang-orang yang takut akan Dia.

Ia ingat untuk selama-lamanya akan perjanjian-Nya.

6 Kekuatan perbuatan-Nya diberitakan-Nya kepada umat-Nya, dengan memberikan kepada mereka milik pusaka bangsabangsa.

7 Perbuatan tangan-Nya ialah kebenaran dan keadilan, segala titah-Nya teguh,

8 kokoh untuk seterusnya dan selamanya, dilakukan dalam kebenaran dan kejujuran.

9 Dikirim-Nya kebebasan kepada umat-Nya, diperintahkan-Nya supaya perjanjian-Nya itu untuk selamalamanya; nama-Nya kudus dan dahsyat.

10 Permulaan hikmat adalah takut akan TUHAN, semua orang yang melakukannya berakal budi yang baik. Puji-pujian kepada-Nya tetap untuk selamanya.

Kraus berpendapat bahwa penggunaan pola akrostik dalam Mazmur 111 menyebabkan kesulitan yang luar biasa dalam menghadirkan parallelismus membrorum. ${ }^{53}$ Pendapat ini benar, oleh karena jika seseorang menganalisa jenis paralelisme dalam Mazmur 111, maka ia akan lebih banyak menemukan paralelisme sintetik daripada paralelisme sinonimus ataupun sintetik. Padahal paralelisme sintetik seringkali dianggap bukan merupakan suatu paralel. $^{54}$

53 Hans-Joachim Kraus, Psalms 60-150, (Minneapolis: Augsburg Publishing House, 1989), 356.

${ }^{54}$ Longman III, Bagaimana Menganalisa, 111. 


\section{Mazmur 112}

Seperti Mazmur 111, Mazmur 112 juga merupakan contoh pola akrostik yang sempurna, karena pola ini rapi berurutan mulai huruf $x$ sampai huruf $\Omega$.

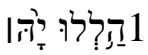

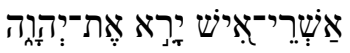

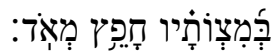

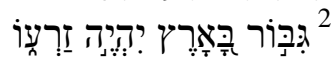

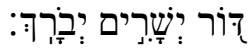

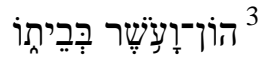

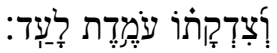

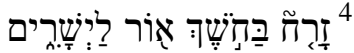

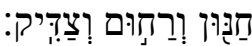

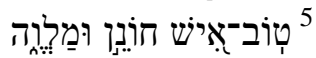

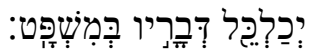

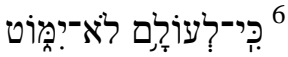

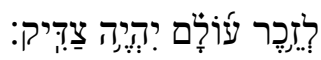

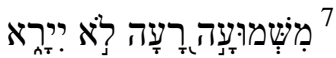

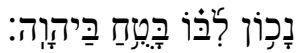

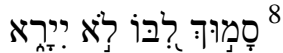

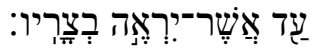

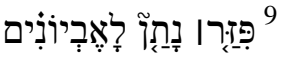

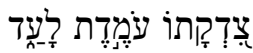

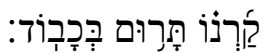

10

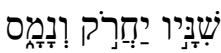

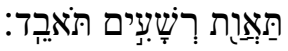


Mazmur 112

1 Haleluya!

Berbahagialah orang yang takut akan TUHAN, yang sangat suka kepada segala perintah-Nya.

2 Anak cucunya akan perkasa di bumi; angkatan orang benar akan diberkati.

3 Harta dan kekayaan ada dalam rumahnya, kebajikannya tetap untuk selamanya.

4 Di dalam gelap terbit terang bagi orang benar; pengasih dan penyayang orang yang adil.

$5 \quad$ Mujur orang yang menaruh belas kasihan dan yang memberi pinzaman, yang melakukan urusannya dengan sewajarnya.

6 Sebab ia takkan goyah untuk selama-lamanya; orang benar itu akan diingat selama-lamanya.

7 Ia tidak takut kepada kabar celaka, hatinya tetap, penuh kepercayaan kepada TUHAN.

8 Hatinya teguh, ia tidak takut, sehingga ia memandang rendah para lawannya.

9 Ia membagi-bagikan, ia memberikan kepada orang miskin; kebajikannya tetap untuk selama-lamanya, tanduknya meninggi dalam kemuliaan.

10 Orang fasik melihatnya, lalu sakit hati, ia menggertakkan giginya, lalu hancur; keinginan orang fasik akan menuju kebinasaan.

Dalam kaitan dengan Mazmur 112 ini, Kraus juga berpendapat bahwa penggunaan pola akrostik dalam Mazmur 112 menyebabkan kesulitan yang luar biasa dalam menghadirkan parallelismus membrorum. ${ }^{55}$ Pengamatan Kraus ini juga benar, oleh karena jika seseorang menganalisa jenis paralelisme dalam Mazmur 112, maka ia akan lebih banyak menemukan paralelisme

${ }^{55}$ Kraus, Psalms 60-150, 362. 
sintetik daripada paralelisme sinonimus ataupun sintetik. Padahal paralelisme sintetik seringkali dianggap bukan merupakan suatu paralel. ${ }^{56}$ Hal yang sangat mirip dengan Mazmur 111.

\section{Mazmur 119}

Mazmur 119 merupakan salah satu contoh terbaik dari mazmur dengan pola akrostik yang dimulai huruf $x$ sampai dengan huruf $\Omega$, yang mana setiap huruf terdiri dari 8 ayat, sehingga jumlah ayat dalam Mazmur 119 adalah 176 ayat.

Kraus berpendapat bahwa penggunaan karya akrostik dalam mazmur ini merupakan sesuatu karya yang luar biasa dan tidak ada yang menyamainya dalam Perjanjian Lama. ${ }^{57}$ Walau Watson mengakui keahlian penyair mazmur ini dalam penggunaan pola akrostik, namun ia juga menunjukkan adanya "kekurangan" atau "keterbatasan" dalam penggunaan kosa kata. ${ }^{58}$ Watson mengungkapkan pola pengulangan kata טוֹ sebanyak 5 kali dalam ayat 65-72 dan kata depanyak 6 kali dalam ayat 97-104. ${ }^{59}$

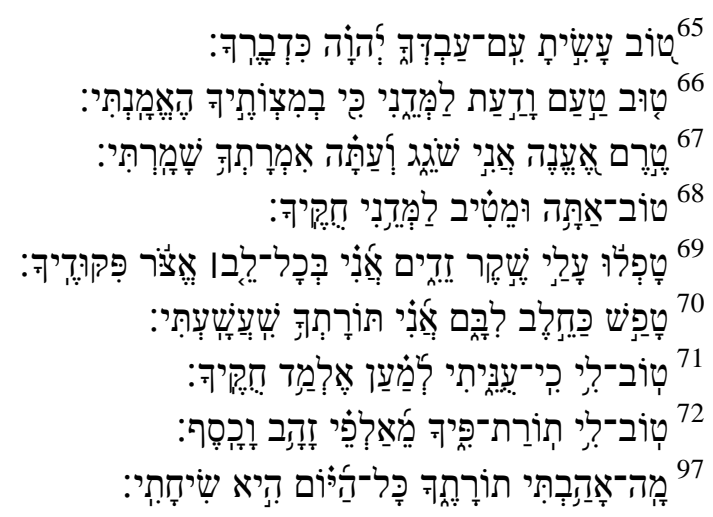

\footnotetext{
${ }^{56}$ Longman III, Bagaimana Menganalisa, 111.

${ }^{57}$ Kraus, Psalms 60-150, 411.

${ }^{58}$ Watson, "Classical Hebrew”, 194.

${ }^{59}$ Watson, "Classical Hebrew”, 194.
} 


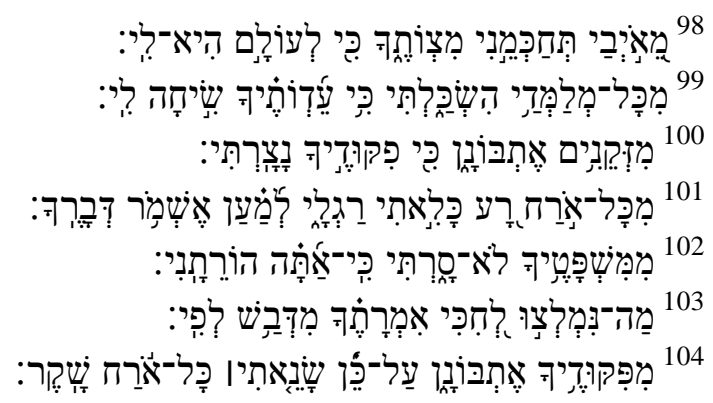

\section{Mazmur 145}

Mazmur 145 merupakan suatu mazmur dengan pola akrostik, walau ada ketidaklengkapan, yaitu tidak adanya pola dengan huruf נ. Kraus berpendapat bahwa hilangnya pola dengan huruf I ini merupakan kerusakan teks. ${ }^{60}$ Watson berpendapat bahwa penghilangan pola dengan huruf I merupakan sesuatu yang disengaja. ${ }^{61}$

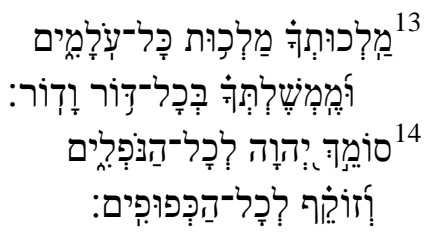

\section{KESIMPULAN}

1. Pola mazmur akrostik adalah pola mazmur yang menggunakan huruf pertamanya berdasarkan pola puitis berurutan berdasarkan alfabet, yang dimulai huruf a sampai huruf $t$. Penyelidikan terhadap mazmur-mazmur yang dianggap sebagai mazmur akrostik, dapat ditemukan bahwa adanya variasi atau ketidaksempurnaan dalam pola akrostik dari suatu mazmur. Terhadap ketidaksempurnaan atau variasi pola akrostik ini ada

\footnotetext{
${ }^{60}$ Band. Kraus, Psalms 60-150, 546.

${ }^{61}$ Watson, "Classical Hebrew”, 193.
} 
para ahli yang berpendapat bahwa hal ini disebabkan oleh kerusakan teks atau peranan editor yang mengubahnya, tetapi ada juga yang berpendapat (Benun, Robertson) bahwa ketidaksempurnaan atau variasi ini memang disengaja oleh penyair dengan tujuan tertentu dalam menyampaikan beritanya.

2. Ada ahli yang berpendapat bahwa kegunaan pola akrostik ini bukanlah untuk proses pembelajaran yang memudahkan untuk mengingat suatu mazmur. Variasi dan ketidaksempurnaan pola akrostik dari beberapa mazmur justru akan memberikan kesulitan dalam proses menghafalnya. Pola akrostik lebih ditujukan pada mereka yang menguasai alfabet dan mempunyai kemampuan membaca, sehingga mereka dapat menemukan keindahan saat membacanya. Sebaliknya ada ahli juga yang berpendapat bahwa pola akrostik ini membantu untuk mengingat suatu mazmur, bahkan dalam konteks yang lebih luas garis besar kitab Mazmur (Robertson).

3. Para ahli umumnya berpendapat bahwa penggunaan pola akrostik dalam mazmur-mazmur ini menunjukkan kemampuan artistik dari seorang penyair, karena pola ini menuntut kemampuan penyair dalam memilih kata dan menyusunnya dalam suatu pola yang baku.

4. Para ahli juga berpendapat bahwa penggunaan pola akrostik ini dapat menyebabkan penyair mempunyai kesulitan tersendiri dalam mengembangkan pola pemikirannya, oleh karena terikat dengan pola yang baku.

5. Studi terkini pola akrostik semakin tidak mempermasalahkan tentang ketidaksempurnaan pola akrostik dan juga tidak berupaya untuk memperbaiki teks untuk mendapatkan pola akrostik yang lebih sempurna, tetapi pola ketidaksempurnaan itu dianggap sebagai sesuatu yang disengaja oleh penyairnya 
dan berupaya untuk menggali makna dari penggunaan pola yang tidak sempurna itu.

\section{DAFTAR RUJUKAN}

Benun, Ronald. "Evil and The Disruption of Order: A Structural Analysis of the Acrostics in the First Book of Psalms", in Journal of Hebrew Scriputres vol. 6, (2006): 1-30.

Ceresko, Anthony R. "THE ABCS OF WISDOM IN PSALM XXXIV," in Vetus Testamentum XXXV, 1, (1985): 100.

Craigie, Peter C. Psalms 1-50. WBC 19. Waco: Word Books, Publishers, 1983.

Freedman, David Noel. "Acrostics and Metrics in Hebrew Poetry", in Harvard Theological Review 65, (1972): 367-92

Freedman, David Noel. "Acrostic Poems in the Hebrew Bible: Alphabetic and Otherwise", in The Catholic Biblical Quaterly, 48, (1986): 408-31.

Kraus, Hans-Joachim. Psalms 1-59. Minneapolis: Augsburg Publishing House, 1988.

Longman III, Tremper. Bagaimana Menganalisa Kitab Mazmur? Malang: SAAT, 1994.

Maloney, Leslie D. A Word Fitly Spoken. Poetic Artistry in the First Four Acrostics of the Hebrew Psalter, (Dissertation, Baylor University, 2005).

Robertson, O. Palmer. "The Alphabetic Acrostic in Book I of the

Psalms: An Overlooked Element of Psalter Structure", in Journal for the Study of the Old Testament vol. 40. 2, (2015): 225-38.

Soll, William Michael. "Babylonian and Biblical Acrostics", in Biblica 69, (1988): 305-23. 
van Eijezeren, M. J. An Exploration into the Translation of Biblical Acrostics, (M.A. Thesis, Utrecht University, 2012).

Watson, Wilfred G. E. "Classical Hebrew Poetry. A Guide to its Techniques", in JSOT Supp. Series 26, (Sheffield: JSOT Press, 1984). 